\title{
Financing Policy of SMEs in China and Abroad in a Comparative Perspective \\ Shuangnan $\mathrm{He}$
}

\author{
Ping'an Street, No.43, Anshan Normal University, Anshan City, liaoning, China
}

59325825@qq.com

\begin{abstract}
Keywords: SMEs; Financial Policy; Management and service organization; Financing guarantee system
\end{abstract}

\begin{abstract}
SMEs promote economic development, solve employment crisis, realize technology innovation and provide competitiveness. This article analyzes the Laws and regulations for SME financing, management grant mechanism and monetary security policy in the United States, UK, Japan and China. By comparing the dissimilarity situation of SMEs among the four countries, this article tries to localize the experiences from the fore-goers.
\end{abstract}

\section{Introduction}

Small and medium-sized enterprises (SMEs) play an irreplaceable role in economic development of all countries in the world. First, SMEs enhance market vitality. In most countries SMEs account for over $95 \%$ of the total number of enterprises, and $99.9 \%$ of the UK and South Korea. This makes it impossible for large enterprises to manipulate the market arbitrarily, which is conducive to fair competition and enhanced market vitality. Second, SMEs provide large number of jobs. Nearly 50 percent of jobs in most countries, such as the US $53 \%$, Germany $78 \%$, and South Korea $87.7 \%$ of the jobs come from SMEs. Third, SMEs create huge social wealth. $75 \%$ of the gross domestic product (GDP) in Germany, 39\% in the United States, is achieved by SMEs. Fourth, SMEs promote economic growth. SMEs build the "Made in Italy" reputation. German SMEs achieved a total investment of $46 \%$, contributed $70 \%$ of the tax and $2 / 3$ of the patented technology.

\section{Laws and Regulations for SME Financing}

The establishment of laws and regulations for SME financing plays a significant role in addressing the financing difficulties. First, good banking laws and regulations ensure the stability and efficiency of banks to avoid strict bank registration and approval system, and promote a number of micro-credit capacities of small banks with credit experience entering the SMEs financing market. Second, the relevant laws and regulations strengthen the protection of financial claims, improve the mortgage system, and reduce the risk and loss of bank loans, which will help banks to expand the SME credit financing.

There are two models for SMEs launch legislative system, single legislation and system legislation: Single legislative model. The United States was the first country to enact the Basic Law for SMEs. It adopted a single legislation model and promulgated more than 100 laws and regulations on SMEs. System of legislative model. The model to Japan and Taiwan are important representatives.

Japan has the most completed SMEs legislative system and adopts system of legislative model, having both the Basic Law, and special laws and regulations. In 1963, Japan developed the "SME Basic Law", which is considered to regulate Japan SMEs, in aspect of SMEs financial institutions, Japan has promulgated the "Central Combination of Commerce and Industry Treasury Law" "National Treasury Act" "SME Financial Treasury Law" . In addition, Japan has also developed a series of SMEs laws involving technological innovation, taxation, fair competition, industry restructuring, and Bankruptcy protection. 
Table 1 Laws and regulations supports SMEs

\begin{tabular}{|l|l|}
\hline Country & Name of regulations \\
\hline \multirow{5}{*}{ America } & $\begin{array}{l}\text { Separate legislative mode, The small business act of 1953, } \\
\text { The small business investment act of 1958, } \\
\text { The equal opportunity act of 1964, Small business finance act } \\
\text { Small business investment encouragement act } \\
\text { Federal Procurement Policy Act of 1974, No. 507 public law } \\
\text { Small Business Technology Innovation law }\end{array}$ \\
\hline UK & $\begin{array}{l}\text { 11laws and regulations support SMEs such as, oppose the industry monopoly, protect } \\
\text { the invention of SMEs, and Solve debt default. }\end{array}$ \\
\hline \multirow{5}{*}{$\begin{array}{l}\text { People's } \\
\text { Republic of } \\
\text { China }\end{array}$} & $\begin{array}{l}\text { The regulation of town collective ownership enterprises } \\
\text { Township enterprises law }\end{array}$ \\
& $\begin{array}{l}\text { 2002, The small and medium-sized enterprises promotion law of the People's } \\
\text { 2003, Provisional rules of small and medium-sized enterprise standard } \\
\text { 2005, Opinions of the development of the private enterprises and other non-public } \\
\text { sectors of the economy }\end{array}$ \\
\hline \multirow{5}{*}{ Japan } & $\begin{array}{l}\text { System legislation mode } \\
\text { 1963, The basic law of small and medium-sized enterprises } \\
\text { Small and medium-sized enterprises promotion law modernization } \\
\text { Small and medium-sized enterprise modernization funds to help the diagnosis } \\
\text { Small and medium-sized enterprise credit insurance public } \\
\text { Small and medium-sized enterprises (SMEs) guidance law. } \\
\text { More than and 50 regulations including financial, technological innovation, tax, fair } \\
\text { competition, bankruptcy protection, including small and medium-sized enterprises, } \\
\text { establishing a relatively complete and relatively independent legal system for small } \\
\text { and medium enterprises. }\end{array}$ \\
\hline
\end{tabular}

\section{The Establishment of Specialized Financial Institutions}

To support SMEs financing governments dedicated competent authorities which can be divided into the United States model and Japan model.

1. US model. The United States is the representative of this model. Government directly provides credit support to SMEs. SBA is the federal agency to help small business financing. SBA performs mainly through secured loans, portfolio loans, Small loans, venture capital funds, relief loan, actually playing a "lender of last resort" role expanding small business credit financing guarantee institution. This specialized establishment for SMEs counterparts in the practice of financial institutions, without interfering in the premise of self-management of commercial banks, highlighting the policy guidance to the development of SMEs, solving the financing difficulties of SMEs effectively. SAB's Headquartered is in Washington having 96 offices and regional offices in 50 states. Besides, the agency set up 1,000 small business development centers nationwide, 17 US export assistance centers, 13 'one-stop capital stores', 39 enterprise information centers, 18 tribal enterprise information centers and 13,000 retired managers voluntarily Service Corps.

2. Japanese model. The model is specifically funded by the Government to help private organizations finance SEMs, represented by Japan and Taiwan. After "World War II" Japan established government-controlled financing institutions providing preferential loans to SMEs , namely The National Finance Corporation, the SME Financial Public Bank, the Commercial and Industrial Central Treasury Bank, the Environmental Health Finance Public Bank and the Okinawa Promotion and Development Finance Corporation. Among them, the National Finance Corporation mainly to provide short-term small liquidity loans, the SME Financial Public Bank focuses on equipment loans and long-term revolving capital loans. 
Table 2: Management and service organization of SMEs

\begin{tabular}{|c|c|c|}
\hline Country & Organization & Function \\
\hline America & $\begin{array}{l}\text { Small Business Administration } \\
\text { (SBA), } 1953\end{array}$ & $\begin{array}{l}\text { States have resident agencies; Macroeconomic } \\
\text { regulation and control policy; Guide the folk } \\
\text { capital to small business investment; To provide } \\
\text { loan guarantees and funding }\end{array}$ \\
\hline UK & Small Business Service(SBS) & $\begin{array}{l}\text { The financing channel looks at the different } \\
\text { funding small business options available to new } \\
\text { and established businesses. }\end{array}$ \\
\hline $\begin{array}{l}\text { People's } \\
\text { Republic of } \\
\text { China }\end{array}$ & $\begin{array}{l}\text { Not establishing a unified small } \\
\text { and medium-sized enterprise } \\
\text { management institutions }\end{array}$ & $\begin{array}{l}\text { Trade and Industry Bureau, Inland Revenue } \\
\text { Department, Finance Bureau etc are all responsible } \\
\text { for the management of SMEs }\end{array}$ \\
\hline \multirow{5}{*}{ Japan } & $\begin{array}{l}\text { Review conference } \\
\text { of SME policy; } \\
\text { Review conference } \\
\text { of SMEs business adjustment }\end{array}$ & $\begin{array}{l}\text { Policy advisory body of the Prime Minister, chief } \\
\text { executive of the provincial and provincial } \\
\text { departments. } \\
\text { Be responsible for policies and laws of SMEs. }\end{array}$ \\
\hline & $\begin{array}{l}\text { SMEs General Office (1948) } \\
\text { affiliated to the Ministry of } \\
\text { international trade and Industry }\end{array}$ & $\begin{array}{l}\text { The Japanese SMEs' highest specialized } \\
\text { administrative agencies, holding eight local } \\
\text { agencies in Japan. Responsibilities: Put forward } \\
\text { policy suggestion }\end{array}$ \\
\hline & Fair Trade Commission & $\begin{array}{l}\text { Handle all kinds of unreasonable phenomenon in } \\
\text { trading activities. }\end{array}$ \\
\hline & $\begin{array}{l}\text { More than } 200 \text { public testing } \\
\text { institutions. } \\
\text { Consultant system }\end{array}$ & $\begin{array}{l}\text { Help SMEs with product development research, } \\
\text { hire technical experts experienced engineering and } \\
\text { technical personnel as a consultant, conduct } \\
\text { feasibility study and test. }\end{array}$ \\
\hline & $\begin{array}{l}\text { 1983, the office automation } \\
\text { system center }\end{array}$ & Promote the modernization management of SMEs, \\
\hline
\end{tabular}

\section{SMEs Financing Guarantee System}

Financing guarantee system will help to improve the credit guarantee ability of SMEs to obtain bank credit financing. In various countries and regions the SMEs financing guarantee system operates in a variety of ways. The operating entities are government departments (such as the US SBA), associations, corporations and specialized banks (such as the Japan Credit Guarantee Association and the Taiwan SME Credit Guarantee Fund). But most of them have a government background and bearing certain compensation liability. SMEs financing guarantee systems have the following common.

1. Sound legal system protection. In most countries and regions, both the credit guarantee business and the operation of the security industry are followed the laws. In Japan "Small and Medium Enterprise Law" is the core, "The Credit Guarantee Association Law and the Credit Insurance Law jointly laid down the legal foundation of the credit guarantee system;

2. Public financial policy. National and regional credit guarantee system is often funded by Governments. Financial capital is the main pillar of the credit guarantee system meanwhile government support is a strong guarantee for long-term sound development of security agencies. In US the assets of SBA are divided into two parts. The basic assets are partly contributed by the federal and states governments. In Japan, the credit guarantee association assets include two parts, in which the basic assets are funded by government, financial institutions and the cumulative balance of income and expenditure constitutes.

3. Establishment of risk dispersion and prevention mechanisms. In the United States Small Business Loan Guarantee Scheme generally does not exceed $75 \%$ to $85 \%$ of the loan. The relevant security-related indicator is defined strictly, such as the maximum limitation of secured loan is from 75 million to 100 million. The duration of secured loan terms is from 2 years to 17 years. 
4. The establishment of risk compensation mechanism. The final risk of the country and regional credit guarantee is basically borne by the government. In the United States, Japan and other countries fixed-funded will be supplemented the credit guarantee fund. The governments yearly allocate the budget in accordance with the amount of credit guarantees to make the ends meet.

Table 3 Financing guarantee system for SMEs

\begin{tabular}{|c|c|}
\hline Country & Descriptions of the financial guarantee system \\
\hline America & $\begin{array}{l}\text { Three levels guarantee systems for SMEs: } \\
\text { SBA directly organizes the National SME credit guarantee system } \\
\text { Local governments set up local professional guarantee system } \\
\text { And the community credit guarantee system }\end{array}$ \\
\hline UK & the Small Firms Loan Guarantee Scheme \\
\hline $\begin{array}{l}\text { People's } \\
\text { Republic of } \\
\text { China }\end{array}$ & $\begin{array}{l}\text { The SME credit guarantee system consists of three parts, the city, provincial and } \\
\text { national level. Province governments are in charge of Re- guarantee issues and city } \\
\text { governments take responsible for guarantee. }\end{array}$ \\
\hline Japan & $\begin{array}{l}\text { Government financial institutions including the national financial treasury, SMEs } \\
\text { financial treasury. Private financial institutions: Urban banks, local banks, credit first, } \\
\text { labor Treasury Treasury. Credit guarantee financial institutions: SMEs Credit } \\
\text { Guarantee Corporation, SMEs Credit Guarantee Association. }\end{array}$ \\
\hline
\end{tabular}

\section{Conclusions}

Suggestions for improvement: In China, The SME Promotion Law still has some shortcomings such as unclear definition of the scope of SMEs, lack of legal coercion, and lack of specific laws and regulations. Therefore, China should improve the laws and regulations system of SMEs as soon as possible. To guide the development of SMEs and create a fair competitive market environment.

\section{Acknowledgments}

Foundation of Anshan Normal University Project 12.5 .

\section{References}

[1] Mid-sized businesses. Gov.uk. Department of Business, Innovation and Skills. Retrieved 11 June 2015.

[2] Bridging loans UK can be used for many purposes. Www.konnectfinancial.co.uk. Konnect Financial. Retrieved 10 October 2015

[3] 2010 to 2015 government policy: government buying. 20 February 2013. Retrieved 9 May 2015.

[4] Business population estimates for the UK and regions 2015

[5] Lv, H.J. (2013) SME Financing Difficulties and Countermeasures. Central China Normal University, Wuhan.

[6] Hirofumi Ueda, Contemporary Japanese small and medium enterprises, Iwanami Shoten, 2004.

[7] Europena Commission, European Observation For SMEs, Executive Summary, 2003 http://smallbusiness.co.uk/financing/

[8] Michaelas, Nicos et al. "Financial Policy and Capital Structure Choice in U.K. SMEs: Empirical Evidence from Company Panel Data." 
[9] Small Business Economics, vol. 12, no. 2, 1999, pp. 113-130. www.jstor.org/stable/40229004.

[10] Juanjuan Jiang, himing Li and Chanyan Lin: Financing Difficulties of SMEs from Its Financing Sources in China, Journal of Service Science and Management, 2014, 7, 196-200 